\title{
ISLAMIC CHARATER SEBAGAI IMPLEMENTASI PENGUATAN PENDIDIKAN KARAKTER DAN ALTERNATIF PEMANTAUANNYA
}

\section{ISLAMIC CHARACTER IMPLEMENTATION OF CHARACTER EDUCATION STRENGTHENING AND THE ALTERNATIVE MONITORING TOOLS}

\author{
${ }^{1)}$ Azmi Fitriati, ${ }^{2}$ Subuh Anggoro, ${ }^{3}$ Sri Harmianto \\ ${ }^{1)}$ Program Studi Akuntansi, Fakultas Ekonomi dan Bisnis \\ ${ }^{2,3)}$ Program Studi Pendidikan Guru SD, Fakultas Keguruan dan Ilmu Pendidikan \\ Universitas Muhammadiyah Purwokerto \\ Jl. KH. Ahmad Dahlan, PO BOX 202, Purwokerto 53182 \\ Email: azmi.fitriati@gmail.com
}

\begin{abstract}
ABSTRAK
Pendidikan karakter merupakan solusi atas permasalahan sosial di Indonesia, seperti peningkatan kriminalitas, pergaulan bebas, penggunaan obat terlarang hingga sikap yang bertentangan dengan nilai dalam masyarakat.Penguatan pendidikan karakter diharapkan dapat menangkal hal-hal tersebut sekaligus meningkatkan hasil belajar baik dalam aspek afektif dan kognitif. Madrasah Ibtidaiyah Muhammadiyah di Kabupaten Banyumas belum memiliki perangkat yang dapat memonitor perkembangan karakter siswanya. Tujuan kegiatan ini adalah (1) mensosialisasikan pentingnya Islamic Character dalam penguatan pendidikan karakter; dan (2) melatih guru dan orangtua siswa melakukan pemantauannya menggunakan buku saku karakter digital. Metode pengabdian yang digunakan yaitu sosialisasi dan pelatihan. Islamic Character dapat dikembangkan oleh MI Muhammadiyah di Kabupaten Banyumas sebagai program penguatan pendidikan karakter. Melalui integrasi karakter dalam kurikulum, kegiatan ekstrakurikuler, maupun penguatan karakter secara khusus dalam nilai-nilai religius, nasionalis, mandiri, gotong royong dan integritas dapat dilakukan secara intensif dan berkelanjutan. Sedangkan aplikasi buku saku karakter digital dapat dijadikan sebagai alternatif pemantauan perkembangan karakter siswa.
\end{abstract}

Kata kunci: Islamic Character; Penguatan Pendidikan Karakter; Aplikasi Buku Saku

\begin{abstract}
Character education can becomes a solution to social problems in Indonesia, such as increased crime, promiscuity, the use of illegal drugs to attitudes that conflict with values in society. Strengthening character education is expected to ward off these things while increasing learning outcomes in both affective and cognitive aspects. Madrasah Ibtidaiyah Muhammadiyah (MIM) Wangon has a vision as an Islamic Character School but did not had a device that can monitor the development of the student's character. The purpose of this program were (1) to socialize the importance of Islamic Character in strengthening of character education; and (2) train teachers and parents using digital character pocket books as an alternative monitoring tool. Methods were used socialization and training. Islamic Character can be developed by MI Muhammadiyah in Banyumas Regency as a program to strengthen character education. Through the integration of characters in the curriculum, extracurricular activities, as well as the strengthening of character specifically in religious, nationalist, independent, mutual cooperation and integrity values can be carried out intensively and sustainably. While the digital character pocket book application can be used as an alternative to monitoring student character development
\end{abstract}

Keywords: Islamic Character; Strengthening of Character Education; Character Pocket Book

Submitted : 18 September 2019 Revision : 30 Oktober 2019 Accepted : 17 Februari 2020 


\section{PENDAHULUAN}

Data Komisi PerlindunganAnak Indonesia (KPAI) mencatat, total pengaduan kasus pornografi dan cyber crime atau kejahatan online yang menjerat anak-anak meningkat dari tahun ke tahun. Data yang tercatat di KPAI dari 2014-2018 sebanyak 322, 463, 587, 608 sampai679 kasus.Adapun jenis aduan diantaranya anak korban kejahatan seksual online, anak pelaku kejahatan online, anak korban pornografi di medsos, anak pelaku kepemilikan media pornografi, dan anak pelaku bullying di medsos.

Untuk membangun negara yang beradab dibutuhkan sumber daya manusia masa depan yang berkualitas. Sumberdaya manusia berkualitas dicirikan oleh beberapa kriteria meliputi cakap, terampil, unggul dalam sains dan teknologi, serta berkarakter baik. Pendidikan karakter saat ini menjadi perhatian utama dalam pendidikan. Karakter dikembangkan atau diajarkan melalui pendidikan, pelatihan sosial dan pengalaman interpersonal (Cheung \& Lee, 2009). Keterampilan sosial dan karakter akan mempengaruhi hubungan dengan teman sebaya (Shields dkk, 2001; Wood dkk, 2004). Keterampilan sosial dan karakter juga berkorelasi dengan masalah perilaku sekolah (Domagala-Zysk, 2006), perilaku antisosial (Arthur \& Kuperminc, 1991), akademik (Hawkins dkk, 1998), dan psikologis (Pedersen dkk, 2007).

Menurut Catalano dkk (2004); Maddox \& Prinz, 2003) karakter juga telah terbukti dapat meningkatkan motivasi akademik, kinerja akademik, self esteem, self efficacy, dan kualitas hubungan dengan rekan. Pendidikan karakter akan memanusiakan, membebaskan alam pikir siswa dalam meraih cita, menghaluskan akal budi, membuatnya tangguh, kuat dan siap menghadapi tantangan kehidupan global.

Sekolah dituntut mampu mengembangkan pendidikan karakter agar terwujud siswa yang berkarakter berbudaya dan bermoral. Tuntutan tersebut sulit terwujud tanpa kesadaran dari pelaksana pendidikan bahwa kualitas pendidikan bukan hanya bertumpu pada kemampuan kognitif, melainkan harus mengembangkan kemampuan yang bersifat afektif dan motorik.
Pemerintah telah menerbitkan Perpres no.87/2017, mengenai Penguatan Pendidikan Karakter. Perpres ini bertujuan membangun dan membekali siswa sebagai generasi emas Indonesia tahun 2045. Pendidikan karakter dianggap menjadi jawaban atas perubahan sosial dalam struktur masyarakat di Indonesia yang kini menghadapi peningkatan kriminalitas, pergaulan bebas, penggunaan obat terlarang hingga sikap yang bertentangan dengan nilai dalam masyarakat.

Pembelajaran merupakan proses individu mengubah perilaku dalam berinteraksi dengan lingkungan, sedangkan lingkungan berhubungan dengan ketersediaan nilai, norma moral sebagai sumber terbentuknya karakter. Dengan kata lain pendidikan yang baik adalah pendidikan yang sarat dengan nilai norma moral yang mendukung tertanamnya karakter yang baik.

Pendidikan karakter merupakan pendidikan yang mengembangkan nilai-nilai budaya dan karakter bangsa pada diri siswa, sehingga mereka memiliki dan menerapkan nilai-nilai tersebut dalam kehidupan dirinya sebagai anggota masyarakat dan warganegara yang religius, produktif dan kreatif.

Secara programatik dapat diartikan sebagai usaha bersama semua guru dan pimpinan sekolah, melalui mata pelajaran dan budaya sekolah dalam membina dan mengembangkan nilai-nilai budaya dan karakter bangsa pada siswa melalui proses aktif siswa dalam proses pembelajaran. Secara teknis memiliki makna sebagai proses internalisasi serta penghayatan nilai-nilai budaya dan karakter bangsa yang dilakukan siswa secara aktif di bawah bimbingan guru. Kepala sekolah dan tenaga pendidikan dalam kehidupannya di kelas, sekolah dan masyarakat.

Salah satu MI Muhammadiyah di Kabupaten Banyumas adalah MIM Wangon. Sekolah tersebut memiliki visi sebagai Islamic Character School. Sekolah membuat program integrasi pendidikan karakter dalam kurikulum. Namun, beberapa MI Muhammadiyah di Kabupaten Banyumas, belum memiliki perangkat yang dapat memonitor perkembangan karakter siswanya. Hal ini menyebabkan mutu layanan khususnya pembinaan karakter kurang terarah. Hal ini berimbas kepada proses pendidikan karakter yang kurang bermutu. 


\section{METODE}

Mitra kegiatan ini adalah kepala sekolah, guru kelas, dan orang tua siswa MI Muhammadiyah di Kabupaten Banyumas. Metode kegiatan yang dilakukan adalah sosialisasi dan pelatihan penguatan pendidikan karakter bagi MI Muhammadiyah di Kabupaten Banyumas. Secara rinci tahapan kegiatan dilaksanakan sebagai berikut:

1. Memberikan pemahaman mengenai islamic character dalam penguatan pendidikan karakter siswa

2. Melakukan pelatihan alternatif pemantauan karakter siswa

3. Melakukan evaluasi pelaksanaan kegiatan

Hasil dari pelaksanaan kegiatan ini, diharapkan mitra dapat menyebarluaskan kepada sesama guru di sekolah lain. MI Muhammadiyah di Kabupaten Banyumas menjadi best practices dalam penguatan pendidikan karakter yang bermutu.

\section{HASIL DAN PEMBAHASAN}

\section{Islamic Character dalam Penguatan Pendidikan Karakter}

Madrasah Ibtidaiyah (MI) atau Sekolah Dasar (SD) Muhammadiyah di Kabupaten Banyumas berjumlah 45 sekolah. Melalui wadah K3S MI Muhammadiyah se Kabupaten Banyumas, program pengabdian pada masyarakat ini dibuat. Kegiatan diselenggarakan di MI Muhammadiyah Pasir Muncang, Jl. Veteran gg. Mawar Pasir Muncang, melibatkan 18 MI/SD Muhammadiyah.

Salah satu visi unggulan MI/SD Muhammadiyah adalah penguatan pendidikan karakter berbasis karakter islam. Program penguatan dilakukan dengan cara mengintegrasikan karakter islam yang sejalan dengan karakter bangsa dalam kurikulum pembelajaran.

Disamping itu penguatan pendidikan karakter juga dapat dilakukan melalui kegiatan ekstrakurikuler, antara lain Hizbul Wathan (HW). HW merupakan salah satu organisasi otonom Muhammadiyah yang bergerak dalam bidang pendidikan kepanduan yang berasaskan al-Qur'an dan Hadits. Fungsi dari Hizbul
Wathan adalah menyiapkan kader Muhammadiyah sejak dini.

Meski kepanduan merupakan pendidikan di luar sekolah/keluarga, tetapi dengan adanya modifikasi yang dilakukan oleh Muhammadiyah, nilai-nilai islam yang ditanamkan di dalam gerakan kepanduannya, maka Gerakan Kepanduan HW dapat dijadikan media kelengkapan Muhammadiyah yang menghidupkan hubungan harmonis antara pendidikan informal (keluarga) dan pendidikan formal (sekolah) dalam menyiapkan kader (Dzikron, 2011)

Hakikat HW adalah pembentukan karakter. Tauhid dan akhlak mulia merupakan pondasinya. HW menyiapkan anggotanya untuk menjadi Kader Muhammadiyah memiliki sikap istiqomah, ikhlas dalam melaksanakan perintahNya, memiliki sifat jujur, amanah, fathanah, dan tabligh (Kwartir Pusat HW, 2014)

Pendidikan karakter melalui kegiatan HW, memiliki esensi dan makna yang sama dengan pendidikan moral dan akhlak. Kriteria manusia, warga masyarakat, dan warga Negara yang baik, didasarkan nilai-nilai sosial tertentu yang berkembang pada budaya masyarakat dan bangsanya.

Untuk mewujudkan kultur sekolah yang berkarakter, pendidikan perlu diarahkan pada tercapainya kebahagiaan dunia akherat. Pendidikan merupakan alat bagi tercapainya tujuan, sedangkan pendidikan itu sendiri dalam prosesnya juga memerlukan alat yakni pengajaran. Sehingga pendidikan dan pengajaran bukanlah memenuhi otak anak didik dengan segala macam ilmu yang belum mereka ketahui, tetapi maksudnya ialah mendidik akhlak dan jiwa mereka, menanamkan rasa fadilah (keutamaan), membiasakan mereka dengan kesopanan yang tinggi, mempersiapkan suatu kehidupan yang suci, ikhlas dan jujur. Semua mata pelajaran haruslah mengandung pelajaran ahklak dan setiap guru harus memperhatikan akhlak (Iqbal, 2013).

Menurut Peraturan Presiden Republik Indonesia Nomor 87 Tahun 2017, terdapat lima nilai utama karakter yang saling berkaitan membentuk jejaring nilai yang perlu dikembangkan sebagai prioritas gerakan penguatan pendidikan karakter. Kelima nilai tersebut merupakan nilai utama karakter bangsa, yaitu religius, nasionalis, mandiri, gotong royong dan integritas. Nilai-nilai utama 
tersebut merupakan cerminan dari islamic character.

Nilai karakter religius mencerminkan keberimanan terhadap Tuhan yang Maha Esa yang diwujudkan dalam perilaku melaksanakan ajaran agama dan kepercayaan yang dianut, menghargai perbedaan agama, menjunjung tinggi sikap toleran terhadap pelaksanaan ibadah agama dan kepercayaan lain, hidup rukun dan damai dengan pemeluk agama lain. Subnilai religius antara lain cinta damai, toleransi, menghargai perbedaan agama dan kepercayaan, teguh pendirian, percaya diri, kerja sama antar pemeluk agama dan kepercayaan, antibuli dan kekerasan, persahabatan, ketulusan, tidak memaksakan kehendak, mencintai lingkungan, melindungi yang kecil dan tersisih.

Nilai karakter nasionalis merupakan cara berpikir, bersikap, dan berbuat yang menunjukkan kesetiaan, kepedulian, dan penghargaan yang tinggi terhadap bahasa, lingkungan fisik, sosial, budaya, ekonomi, dan politik bangsa, menempatkan kepentingan bangsa dan negara di atas kepentingan diri dan kelompoknya. Subnilai nasionalis antara lain apresiasi budaya bangsa sendiri, menjaga kekayaan budaya bangsa, rela berkorban, unggul, dan berprestasi, cinta tanah air, menjaga lingkungan, taat hukum, disiplin, menghormati keragaman budaya, suku,dan agama.

Nilai karakter mandiri merupakan sikap dan perilaku tidak bergantung pada orang lain dan mempergunakan segala tenaga, pikiran, waktu untuk merealisasikan harapan, mimpi dan cita-cita. Subnilai mandiri antara lain etos kerja (kerja keras), tangguh tahan banting, daya juang, profesional, kreatif, keberanian, dan menjadi pembelajar sepanjang hayat.

Nilai karakter gotong royong mencerminkan tindakan menghargai semangat kerja sama dan bahu membahu menyelesaikan persoalan bersama, menjalin komunikasi dan persahabatan, memberi bantuan/pertolongan pada orang-orang yang membutuhkan. Subnilai gotong royong antara lain menghargai, kerjasama, inklusif, komitmen atas keputusan bersama, musyawarah mufakat, tolongmenolong, solidaritas, empati, anti diskriminasi, anti kekerasan, dan sikap kerelawanan.
Nilai karakter integritas merupakan nilai yang mendasari perilaku yang didasarkan pada upaya menjadikan dirinya sebagai orang yang selalu dapat dipercaya dalam perkataan, tindakan, dan pekerjaan, memiliki komitmen dan kesetiaan pada nilai-nilai kemanusiaan dan moral (integritas moral). Subnilai integritas antara lain kejujuran, cinta pada kebenaran, setia, komitmen moral, anti korupsi, keadilan, tanggungjawab, keteladanan, dan menghargai martabat individu (terutama penyandang disabilitas).

Pelaksanaan gerakan penguatan pendidikan karakterberbasisIslamic Characterdapat dilakukan melalui empat cara, yaitu: (1) Mengintegrasikan pendidikan karakter pada mata pelajaran yang ada di dalam struktur kurikulum dan mata pelajaran muatan lokal (mulok) melalui kegiatan intrakurikuler dan kokurikuler; (2) Nilai-nilai utama penguatan pendidikan karakter diintegrasikan ke dalam mata pelajaran sesuai topik utama nilai karakter yang akan dikembangkan/dikuatkan pada sesi pembelajaran tersebut dan sesuai dengan karakteristik mata pelajaran masing-masing; (3) Mengimplementasikan penguatan pendidikan karakter melalui kegiatan ekstrakurikuler; dan (4)Kegiatan pembiasaan melalui budaya sekolah dibentuk dalam proses kegiatan rutin, spontan, pengkondisian, dan keteladanan warga sekolah.

\section{Alternatif Pemantauan Penguatan Pendidikan Karakter}

Pemantauan karakter siswa merupakan bagian penting dalam penguatan pendidikan karakter. Akan tetapi,karena guru tidak dapat sepenuhnya mendampingi perkembangan karakterpeserta didik, maka guru memerlukan perangkat untuk pemantauan terhadap karakter peserta didik. Salah satu alternatif pemecahan masalah tersebut adalah dengan menggunakan buku saku karakter siswa.

Buku saku karakter berguna bagi guru/wali kelas dalam melakukan pemantauan karakter siswa. Melalui buku saku karakter, siswa diberikan kepercayaan untuk melakukan penilaian terhadap diri sendiri, sebagai bentuk penanaman kejujuran pada siswa. Disamping itu orangtua atau wali murid dilibatkan dalam 
proses pemantauannya. Sehingga dapat disinergikan antara siswa, orang tua dan sekolah dalam gerakan nasional revolusi mental melalui penguatan pendidikan karakter

Penggunaan buku saku karakter merupakan kegiatan pembiasaan yang ditetapkan sekolah bagi siswa untuk memperkuat pembentukan karakter yang diharapkan. Sekolah dapat menerapkan kelima nilai utama karakter bangsa secara bertahap. Nilai-nilai tersebut ditetapkan berdasarkan visi dan misimasing-masing sekolah.

Alternatif pemantauan perkembangan karakter siswa dapat dilakukan manual. Akan tetapi hal itu akan menyulitkan bagi guru. Setiap hari buku saku karakter diisi secara manual baik oleh siswa maupun oleh guru kelas. Mereka memberi cek list $(\sqrt{ })$ pada aktivitas yang telah dilaksanakan oleh siswa di sekolah maupun di rumah. Selanjutnya guru kelas dan wali murid akan mengkonfirmasi dan memvalidasi dengan cara membubuhkan paraf untuk keseluruhan aktivitas yang dilaksanakan pada setiap harinyaselama satu tahun ajaran.

Jika guru kelas di MI Muhammadiyah Kabupaten Banyumas memantau 20-30 siswa. Dan jika indikator karakter yang dipantau sebanyak 10 item, maka setiap hari guru kelas harus memantau dan membuat cek list sebanyak 200-300 aktivitas yang dilakukan oleh semua siswa di kelasnya setiap hari.

Hal ini tentu sangat menyibukkan guru kelas. Selain itu, guru kelas juga harus membuat laporan rekapitulasi pelaksanaan aktivitas tersebut setiap semester, dan itu sangat menyita waktu guru kelas agar bisa memantau semua aktivitas/indikator karakter untuk semua siswa.

Model penguatan pendidikan karakter tersebut, juga menyebabkan siswa, orang tua dan guru hanya terfokus pada rutinitas pencatatan dan pelaporan atas pelaksanaan aktivitas/ indikator karakter saja. Guru kelas belum dapat menitikberatkan proses evaluasi dan perbaikan karakter siswa.

Penggunaan teknologi informasi (aplikasi online) merupakan salah satu alternatif dalam penguatan pendidikan karakter siswa. Aplikasi inidapat memudahkan guru kelas dan orang tua dalam mengakses dan memberikan informasi kondisi/karakter siswa. Sehingga dengan adanya aplikasi tersebut dapat menghasilkan informasi yang cepat, tepat, akurat, relevan dan lengkap (DeLone dan McLean, 1992; 2003).

Aplikasi buku saku karakter digital didesain untuk memberikan kemudahan, user friendly dan fleksibel sehingga dapat digunakan juga oleh sekolah lain. Aplikasi buku saku karakter bisa diakses oleh guru dan orangtua melalui smartphone. Aplikasi tersebut dilengkapi fitur yang dapat diakses oleh user baik guru, dan orangtua siswa sesuai dengan kewenangannya.

Dalam aplikasi tersebut, orang tua terlibat dalam pembentukan karakter anak. Orang tua dapat mengingatkan anak untuk senantiasa berperilaku baik. Guru mempunyai lebih banyak waktu untuk membentuk karakter siswa. Sehingga orang tua dan guru bisa bekerjasama memantau, mengevaluasi dan memperbaiki perilaku anak sehari-hari baik di sekolah maupun di rumah. Diharapkan perilaku baik siswa akan membentuk akhlakul karimah (islamic character) dalam kehidupan hingga akhir hayatnya.

\section{SIMPULAN}

Islamic Character dapat dikembangkan oleh MI Muhammadiyah di Kabupaten Banyumas sebagai program penguatan pendidikan karakter. Melalui integrasi karakter dalam kurikulim, kegiatan ekstrakurikuler, maupun penguatan karakter secara khusus dalam nilai-nilai religius, nasionalis, mandiri, gotong royong dan integritas dapat dilakukan secara intensif dan berkelanjutan. Kegiatan ini menjadi pendukung penting dalam proses pembelajaran yang berkarakter Islami.

Pemantauan perkembangan karakter siswa dalam upaya penguatan pendidikan karakter dapat dilakukan melalui buku saku karakter, baik secara manual maupun menggunakan sistem informasi. Melalui aplikasi buku saku karakter digital guru, orangtua dan sekolah dapat melakukan pemantauan perkembangan karakter siswa secara mudah, user friendly dan fleksibel.

\section{DAFTAR PUSTAKA}

Arthur, M.W., \& Kuperminc, G.P. (1991). Social competence predictors of antisocial behavior. Paper presented at the biennial 
meeting of the Society for Research in Child Development, Seattle, WA

Bidang Diklat Kwartir Pusat Hizbul Wathan, (2014). Bahan Pelatihan Jaya Melati II (Yogyakarta: Kwartir Pusat Gerakan Hizbul Wathan)

Catalano, R.F., Haggerty, K.P., Oesterle, S., Fleming C.B., \& Hawkins, J.D. (2004). The Importance Of Bonding To School For Healthy Development: Findings From The Social Development Research Group. Journal of School Health, 74(7), 252-61

Cheung, C., \& Lee, T. (2009). Improving Socialcompetence Through Character Education. Evaluation and Program Planning. 33, 255-63

DeLone, W.H. and McLean, Ephraim R. (1992). Information Success The Quest For Dependent Variable. Information System Research. 3(1), 60-95

DeLone, W.H. and McLean, Ephraim R. (2003). The DeLone and McLean Model of Information Systems Success: A Ten Year Update. Journal of Management Information Systems. 19(4),9-30

Dzikron, M. (2011). Keterampilan Kepanduan Hizbul Wathan (Klaten: Hizbul Wathan Scouting Movement Of Indonesia)

Domagala-Zysk, E. 2006. The Significance Of Adolescents' relationships with significant othersand school Failure. School Psychology International. 27, 232-247

Hawkins, J.D., Farrington, D.P., \& Catalano, R.F. (1998). Reducing violence through the schools. In D. S. Elliot, B. A. Hamburg, \& K. R. Williams (Eds.), Violence in American schools: A new perspective (pp. 186-216). New York, NY: Cambridge University Press

Iqbal, A.M., (2013), Konsep Pemikiran AlGhazali tentang Pendidikan, Madiun : Jaya Star Nine

Maddox, S.J., \&Prinz, R.J. (2003). School Bonding In Children And Adolescents: Conceptualization, Assessment And Associated Variables. Clinical Child and Family Psychology Review, 6(1), 31-49

Pedersen, S., Vitaro, F., Barker, E.D., \&Borge, A.I.H. (2007). The Timing Of MiddleChildhood Peer Rejection And Friendship: Linking Early Behavior To Early Adolescent Adjustment. Child Development, 78(4), 1037-1051

Peraturan Presiden Republik Indonesia Nomor 87 Tahun 2017 tentang Penguatan Pendidikan Karakter

Shields, A., Ryan, R.M., \&Cicchetti, D. (2001). Narrative Representations Of Caregivers And Emotion Dysregulation As Predictors Of Maltreated Children's Rejection By Peers.Developmental Psychology. 37. 321337

Wood, J.J, Emerson, N.A., \& Cowan, P.A. (2004). Is Early Attachment Security Carried Forward Into Relationships With Preschool Peers? British Journal of Developmental Psychology. 22. 245-253. 